\title{
Revival, Recognition, Restitution: Indigenous Rights in the Eastern Caribbean
}

\author{
Amy Strecker*
}

\begin{abstract}
The idea that the indigenous peoples of the Caribbean islands became extinct has until recently dominated scholarly discourse and popular awareness. This "extinction" narrative served to justify the appropriation of indigenous lands during the colonial period, and its legacy continued into post-independence. In recent years, these misconceptions have been put under increasing scrutiny, not only by archaeological, historical, and ethnographic research but also, more importantly, by communities themselves. In Dominica, Saint Vincent, and Trinidad, communities are contesting negative stereotypes, reasserting their presence, and agitating for their human rights in the postcolonial islands states. This article discusses the acquisition of indigenous rights by descendant communities in the eastern Caribbean. It reveals the various degrees to which communities have gained state recognition and illustrates that while progress has been made in relation to recognition and cultural rights for communities in the islands, issues remain in relation to land security.
\end{abstract}

\section{INTRODUCTION}

While the restitution debate has developed substantially since the Second World War, this is not necessarily the case for the Caribbean islands. Although archaeological

\footnotetext{
^Faculty of Archaeology - World Heritage, Leiden University, Netherlands; Email: a.strecker@arch. leidenuniv.nl

ACKNOWLEDGMENTS: I would like to express my gratitude to the following people for sharing their views and experience: Ricardo Bharath Hernandez (Santa Rosa First Peoples' Community), Irvince Auguiste and Cozier Frederick (Kalinago Territory), and Zoila Ellis Browne (Garifuna Heritage Foundation). Thanks also to Melanie Newton, Jimmy Mans, and Eloise Stancioff for helpful comments and editing on earlier drafts of the text. Any remaining errors are my own. This research was made possible thanks to the ERC-Synergy Project entitled NEXUS 1492: New World Encounters in a Globalizing World, directed by Corinne Hofman at Leiden University and funded by the European Union's Seventh Framework Programme's European Research Council Grant Agreement 319209 (FP7/2007-2013).
} 
and ethnographic objects belonging to Caribbean states have long been expropriated, the restitution debate has not played as essential a role in post-colonial discourse in the islands as in other former colonies. This lack of debate is due to many reasons. First, most of the cultural objects outside the Caribbean and in European and US collections pre-date 1492 and are perceived to be culturally linked to preColumbian, rather than the present day, multi-ethnic Caribbean societies. Second, these collections have not been studied or catalogued to any great extent, thus precluding the basic knowledge required for restitution claims. ${ }^{1}$ Third, the remaining indigenous communities on the islands, many of whom live in Dominica, Saint Vincent, and Trinidad, have been actively concerned with issues other than the restitution of cultural objects. Against the traditional historical narratives of extinction, the islands' indigenous peoples have been focused on cultural revival, gaining recognition, and seeking restitution in the post-independence era.

This article discusses the acquisition of indigenous rights and restitution in relation to communities in Dominica, Saint Vincent, and Trinidad. Restitution here is taken to mean restitution in the broadest sense-as (1) the act of restoring something lost or stolen to its rightful owner and (2) recompense for injury or loss. $^{2}$ This article therefore uses the term to discuss issues broader than the return of cultural property, such as struggles for recognition, cultural revival, and land rights in post-colonial island states. As stated by Rose-Marie Belle Antoine, with reference to Caribbean Commonwealth legal systems, "if law has largely failed to acknowledge the customs and norms of important groups in society ... it is fair to say that it has completely ignored the original peoples." 3 She later adds that "whether the reform of law is manifested in politics or property matters, it must be emancipated from its past. In short, the law must be repatriated."4 It is this notion of repatriation - the detangling of the legal framework from its colonial baggage - that is inferred in this article.

The reason for focusing on the Caribbean islands and not the circum-Caribbean more generally is due to a number of reasons. First, the idea that the islands' indigenous peoples were driven to extinction within a few decades of European presence still pervades popular awareness and scholarly discourse, despite the efforts of Caribbean scholars to challenge this notion. ${ }^{5}$ Second, scant attention has been paid by legal scholars to the subject of indigenous rights in the islands, in contrast to the prevailing commentary on the mainland's indigenous communities, especially in Suriname, Belize, and Guyana. This lack of attention is understandable given the level of indigenous rights violations in the latter countries, some of which have been the subject of proceedings before the Inter-American Court of Human Rights and the Caribbean Court of Justice. ${ }^{6}$ In addition, the islands' self-identifying indigenous communities are relatively small when compared to the mainland's populations, and there is an entire absence of case law dealing with indigenous land rights claims in the islands compared to the mainland.

Yet these reasons do not justify the dearth of research into the current situation of island communities; communities that have gained significant progress 
in recent decades by challenging official narratives and re-appropriating some of the cultural and political space they had previously been denied. The following analysis is divided into four parts. The first part outlines the context and parameters of international law and indigenous peoples in the Caribbean. The second provides a brief historical background of the indigenous communities in Dominica, Saint Vincent, and Trinidad. The third and main part of the article then charts the recent developments in the acquisition of indigenous rights in the islands, with reference to the relevant international framework. It discusses the most recent initiatives in government support and recognition for the respective communities and discusses the issue of land restitution. Lastly, conclusions will be drawn relating to these developments and outstanding issues on the ground in the islands.

\section{INTERNATIONAL LAW AND THE INDIGENOUS CARIBBEAN}

The history of Caribbean indigenous peoples is closely connected with early international law. First, the conflict inherent in Spanish colonialism was played out in the Caribbean, with brutal policies directed toward the native populations, on the one hand, justified by legal theorists such as Juan Ginés de Sepúlveda, and more humane but nevertheless civilizing mission policies, on the other, consistent with the writings of Bartolomé de Las Casas and international jurist Francisco de Vitoria.7 Later, under British colonial administration, it was Thomas Hobbes's theories of sovereignty and dominion that bolstered the political tenets of expansionism, and it was Lockean doctrine that justified the need for resource expansion in the name of utilizing uncultivated lands. ${ }^{8}$ International instruments also played a role, the most significant for the present purposes being the Treaty of Aix-la-Chappelle of 1748, which paved the way for British and French claims of ownership over Dominica and Saint Vincent and ignored indigenous claims enshrined in earlier treaties (namely those of 1660 and 1668). ${ }^{9}$

International law continues to play a role in Caribbean indigenous affairs today, albeit in a radically different way to the past. While early international law served as a "tool of empire" by nation states, ${ }^{10}$ it is now purported as a "vehicle for change" for the people it had previously been utilized to subvert. ${ }^{11}$ For instance, the resurgence or revival of indigenous identity toward the end of the twentieth century coincided with a rise in the international indigenous movement, and the most recent changes in national policies attempt to placate international standards. ${ }^{12}$ In this sense, the Caribbean continues to represent wider movements taking place on a global stage, both politically and ideologically. Yet a number of factors make the situation of the Caribbean unique from that of other former colonies. First, independence came relatively late to some of the islands-as late as the 1980s in certain cases-and, second, the Caribbean is significantly more heterogeneous than most of the world's regions, which has been used by some authors to undermine the legitimacy of indigenous claims. ${ }^{13}$ 
It is true that a contradiction exists between the legal approaches to culture, on the one hand, and the unstable conception of culture that pervades the social sciences, on the other. Ronald Niezen terms this dichotomy as "flux and boundary," the former referring to the constructivist approach to culture, while the latter refers to the positing of communities as bounded entities, with inherent cultural characteristics. ${ }^{14}$ Yet these approaches are not mutually exclusive. Peter Hulme proposes that the terms often used to describe Caribbean indigeneity_ "survival" or "invention," depending on one's view - are in fact anti-essentialist forms of identity formation that represent a unique ethnicity, determined as much by cultural contact as by miscegenation. Hulme further notes that indigenous claims based on distinctive ethnicity as the earliest inhabitants of a particular place can be scrutinized by cultural criticism, but that these claims "cannot and should not be ignored."15

Hulme is right, of course, not only due to the disproportionate injustice suffered by indigenous peoples historically (and still in many parts of the world today) but also due to the ongoing inequalities or legacies that exist as a result of this historical injustice, often in post-colonial societies. When discussing the law, therefore, we are dealing with two temporalities, both historical (restorative justice) and contemporary (the situation of ethnic groups in present day societies, which may be the subject of discrimination due to ethnic attachment). In short, it is not the existence of actual grave human rights violations that gives rise to the attention to indigenous rights in the island states but, rather, the fact that these communities have had to overcome dominant historical narratives that, on the one hand, belie their existence (extinction) and, on the other, attach derogatory associations (cannibalism). As noted by Basil Reid, "one of the greatest falsehoods still inscribed in our history books is the notion that the Island-Caribs were cannibals." 16

The myth of cannibalism supported the notion that the island people were somehow inferior, or savage, thus justifying external interference, and it was not unique to the Caribbean. ${ }^{17}$ What is striking, however, is the extent to which these two narratives continue to impact upon present day discourse. For example, until the end of 2014, a section on "Amerindian occupation" in the web portal of the Chaguaramas Development Authority (Trinidad) read: "There was another Amerindian tribe, a fierce tribe known as Caribs. This tribe pounced on the Arawaks and were known to be cannibals (eaters of human flesh). The Caribs had devoured their way up the Caribbean islands." 18 This official narrative is currently changing in the islands and slowly being replaced by a more nuanced narrative, with a shift in the terminology to match, as will be shown in the sections to follow.

\section{THE INDIGENOUS PEOPLES OF THE EASTERN CARIBBEAN}

\section{The Indigenous Peoples of Dominica and Saint Vincent}

The indigenous peoples of Dominica and Saint Vincent, the Kalinago, maintained control of the Windward Islands from about 1400 until 1700, with Dominica and 
Saint Vincent holding out for a number of decades thereafter. ${ }^{19}$ Referred to as "Island Caribs" by the Europeans, the Kalinago presented the greatest resistance to European colonization of the region, and, already in the 1660s, several treaties were concluded acknowledging their land rights in the islands. For example, the 1660 Treaty, initiated by the French administrator of Saint Christopher, Du Poincy, and signed by 15 of the "most renown Caribs of St. Vincent and Dominica and those who have been driven to the east of Martinique," guaranteed possession of Dominica and Saint Vincent to the indigenous people on the condition that they abandon their claims to other islands. ${ }^{20}$ The terms of the treaty were also accepted by the British but were later violated by both European parties. In subsequent treaties, clauses determined what could be left to the native populations, implying that the rest was legitimately possessed. After 1763, when both islands were formally ceded to Britain under the terms of the Treaty of Paris, island surveys were drawn and lots of land auctioned in London. The indigenous peoples were forced to the harsh Atlantic coasts of both islands. While the islands of Dominica and Saint Vincent shared a similar historical trajectory up until this point, the fate of the islands' people differed drastically in the remaining years of indigenous resistance.

\section{Dominica}

In Dominica, 232 acres were set aside for the indigenous population on the north-east Atlantic coast. This small acreage was later expanded to 3,700 acres in 1903 by a British administrator, Sir Hesketh Bell: "This surviving remnant of the race has been so badly treated in the past that a little kindness to them in the future may not be considered Quixotic." ${ }^{21}$ Since the Kalinago Territory is the only such constituted legal space in the archipelago, it is often-erroneously-cited as being the last place of indigenous presence in the Caribbean. When Dominica became independent from Britain in 1978, the Kalinago Territory was legislated for under the Carib Reserve Act of 1978. ${ }^{22}$ The act granted collective title to the residents of the Kalinago Territory and legally instituted the position of the Kalinago Chief and Council to be elected every five years by residents of the territory.

In 2002, Dominica became the first Caribbean state to ratify the International Labour Organization's (ILO) Convention No. 169 Indigenous and Tribal Peoples. ${ }^{23}$ This was due in part to the advocacy and lobbying of the then chief of the territory at the international level. Yet while indigenous communities in other islands often look to Dominica as the ideal scenario, issues remain in relation to land security and socio-economic development. Education, employment, and logistics place the territory's residents at the bottom of the occupational hierarchies in each sector. ${ }^{24}$ In 2010, the Country Poverty Assessment revealed "the Native community faces the highest level of general social disadvantage, even though they are well integrated into the society. This ethnic group suffers mainly from lingering forms of discrimination." 25 It also noted that in respect of ethnic origin, indigenous persons in Dominica were more likely than any other group in the population to be poor 
and that 49.8 percent of the Kalinago population were found to be living below the poverty line. $^{26}$

In addition, Dominica illustrates a common paradox within tourism that its poorest community - that is, the Kalinago-is itself a tourist attraction, contributing to the distinctive image promoted by the island, even though potential Kalinago guides and vendors are dissociated from opportunities of equitable tourism revenue. ${ }^{27}$ Furthermore, the exact borders of the Kalinago Territory as demarcated in 1903 have never been clarified, leading to insecurity in relation to land encroachment and the exact nature of the rights of the Kalinago over lands located in disputed areas. At a land meeting on 4 July 2014 (as part of the annual commemoration of the establishment of the territory in July 1903), ${ }^{28}$ one of the community elders stood to read this passage from Hesketh Bell's report on the Kalinago of 29 July 1902:

It appeared to me very desirable that the limits of the Reserve should be properly and finally delimited, and I commissioned Mr. A. Skeat, a licensed surveyor, to survey the land held by them and to make a plan. He was instructed to follow the recognized boundaries of the Reserve and to adopt, wherever possible, streams, cliffs, and other natural landmarks. He was also authorized to include that part of the Hatton Garden Valley in which their cocoa and other plantations are situated. ${ }^{29}$

Although referred to in H. Bell's report, the Hatton Garden valley and adjacent lands are no longer a part of the Kalinago Territory. It is for these reasons that old documentation and maps are important, as it is believed that these documents might help to clarify the territory's borders and contribute to the resolution of disputes. However, much of the historical record relating to Kalinago history is located in archives in Europe, particularly at the British National Archives in London, which poses problems of accessibility.

\section{Saint Vincent}

During the seventeenth century, shipwrecked and/or runaway slaves joined together with the local Kalinago population of Saint Vincent to form a distinct society, the Garifuna, referred to by the Europeans as "Black Caribs." 30 They mounted considerable resistance to British occupation of Saint Vincent, which was the last indigenous resistance in the region, culminating in the "Black Carib revolt" of 1796, what Christopher Taylor refers to as the "Wounded Knee" of the region. ${ }^{31}$ When the Garifuna lost the war, the British rounded up much of the remaining population, somewhere between 4,336 and 5,080 indigenous men, women, and children, and forcibly removed them, first to the island of Balliceaux and, eight months later in 1797, to Roatán, an island off the coast of Honduras and Belize. ${ }^{32}$ Only about half of those banished to Balliceaux arrived on Roatán, as many had died from starvation and disease on the journey.

Despite these events, the Garifuna population grew considerably from the relatively small numbers who made it to Roatán, and they now live throughout 
the Caribbean mainland in Honduras, Belize, Nicaragua, and Guatemala (with quite a substantial diaspora in the United States). What is noteworthy is that the Garifuna maintained a strong cultural identity, which is rooted in their past as a free people living in Saint Vincent. The Garifuna language is still spoken, even though Amerindian languages are no longer spoken on the islands themselves. ${ }^{33}$ The Garifuna maintained other cultural practices, such as the dugu ritual, ${ }^{34}$ and Garifuna cosmology invokes a very specific notion about the land and how it is to be treated. ${ }^{35}$ Despite over 200 years of absence, Saint Vincent (Yurumein) is still considered to be the Garifuna ancestral homeland, just as Balliceaux Island is considered a pilgrimage site and place of memory. Indeed, Balliceaux was the subject of a plea on the part of the Garifuna Council of Belize to the government of Saint Vincent in 2005, to attempt to block its private sale for tourist development. The letter reads:

Balliceaux is a monument to the suffering and survival of indigenous people against incredible odds. Let it be so declared, so preserved, honored and respected. I am sure that we speak for all Garinagu in pledging our support to you and to your Government in this regard. We stand ready to work with you to do whatever is necessary for the safeguarding of Balliceaux as a monument most fitting to those Garifuna men, women and children who fought and died to defend our homeland, our freedom, our human dignity and our culture. ${ }^{36}$

Conversely, the indigenous people who remained in Saint Vincent after the forced removal, who were more numerous than previously admitted, eventually ceased to speak their language and maintain their culture. ${ }^{37}$ As noted by Melanie Newton, in the aftermath of the exile, "the remaining indigenous Vincentians faced a new legal existence as barely tolerated guests in their own homeland." 38 The two trajectories of the Garifuna presented above imply two dimensions to the question of land rights in Saint Vincent. The first relates to the indigenous people who remained in Saint Vincent after the mass exile of 1796 and who were later granted some acreage on the north Atlantic coast at Sandy Bay. ${ }^{39}$ Despite the fact that the area is still known locally as "Carib country," the current residents do not hold any collective title to the land.

The other dimension to land centres on whether the Garifuna population outside of Saint Vincent have rights in relation to land on the island. This is an increasingly important factor for the Garifuna who cannot access lands in their countries of residence-for example, in Belize-as they are often excluded from consideration in land rights claims, even in the areas where they reside alongside Mayan communities. ${ }^{40}$ Part of the reason for this exclusion, as pointed out by Joseph Palacio, Carlson Tuttle, and Judith Lumb, is that funders have difficulty accepting black people as indigenous, even if they practice indigenous ways of life and co-manage natural areas such as the Sarstoon-Temash National Park. ${ }^{41}$ This is a different matter in Honduras, where the arrival of the Garifuna preceded the foundation of the modern state and where communities do have collective land title, even though land rights violations are commonplace. 


\section{The Indigenous Peoples of Trinidad}

Trinidad's indigenous history differs substantially to that of Dominica and Saint Vincent. While the latter islands are traditionally associated with indigenous resistance and continuity, Trinidad's indigenous population was essentially erased from the official record during the nineteenth century. This is despite the fact that Trinidad had one of the longest histories of human settlement in the Caribbean, with various tribes of differing origin from the mainland settling there. Indeed, the earliest known human remains of the Caribbean were found at Banwari Trace in Trinidad (dating to circa 7,000 years ago). According to Boomert, the indigenous population was estimated at between 35,000 and 40,000 around the time of Spanish settlement. ${ }^{42}$

Yet despite the long indigenous occupation of Trinidad, no treaties existed granting or acknowledging native land rights. Indeed, Maximilian Ricardo Forte and Bharath Hernandez note that much of the documentation in the early years of British administration (after Trinidad was ceded to Britain in 1802) portrayed Trinidad as a virtual "terra nullius." 43 From the mid-nineteenth century onwards, Trinidad's indigenous population ceased to be recorded at all; they had essentially been written out. ${ }^{44}$ The erasure from the official record did not reflect the reality on the ground, especially since some indigenous communities, such as those on the missions, continued to practise their cultural traditions and identify strongly with their indigenous ancestry.

A prime example of such a community is the Santa Rosa First Peoples' community of Arima. ${ }^{45}$ The community owes its name to the mission dedicated to the patron Saint of Lima, Saint Rose, which was established in Arima between 1785 and 1786 by the last Spanish governor of Trinidad. ${ }^{46}$ Following the Cédula de Población in 1783 and the consequent clearing of lands to make way for newly arrived planters, three "Amerindian" encomiendas-Cuara, Tacarigua, and Aroucawere uprooted and moved to Arima, where approximately 1,000 acres of land were granted for the inalienable use of the inhabitants. ${ }^{47}$ This area was later expanded by 320 acres by British Governor Ralph Woodford. In 1849, the Territorial Ordinance was passed, which divided the island of Trinidad into lots, which were then sold. Among the lots for sale were the mission lands at Arima. Justifications for appropriation included the lack of proof of title and the notion that the community was "almost extinct," which was supported by the restrictive recording of the indigenous population in parish records. ${ }^{48}$ This was despite the fact that the community still continued to live and practise traditions in Arima and still do to the present day.

According to various sources, the inhabitants of the Santa Rosa mission converted to Catholicism under the Capuchin friars but maintained a strong link to their indigenous heritage, which the community maintained and adapted over time. The expression of the community's identity became encapsulated in the Santa Rosa Festival, an annual cultural event that continues to be celebrated by 
the community to this day and which, interestingly, has its origins in the patronal feasts of early Indian encomiendas. ${ }^{49}$ Arima is home to the only "Carib Queen" in the Caribbean, a titular role dating back to the establishment of the mission and closely tied to the Santa Rosa Festival. According to Forte, who carried out extensive ethnographic fieldwork in Arima during the 1990s, the contemporary queen represents a "convergence of cultural influences and traditions of sorts, fossilized elements of practices pertaining to different moments in the history of Arima's Amerindians." 50 The queen's role within the community is both ceremonial, as a figurehead with traditional knowledge and standing within the community, and organizational, in so far as she is responsible for directing the preparations for the festival. The festival itself ensures a cultural cohesiveness of the community in the absence of a physical land base.

In the aftermath of independence, the chief of the Santa Rosa First Peoples' Community applied to have the Santa Rosa community formally recognized by the state. After many years of lobbying, with the assistance of British archaeologist Peter Harris from the University of the West Indies, a form of government recognition came in 1990. Press Release No. 360 of the Information Division under the Office of the Prime Minister announced that "Cabinet has decided that the Santa Rosa Carib Community be recognized as representative of the indigenous Amerindians of Trinidad and Tobago," and it granted an annual subvention of TT \$30,000. ${ }^{51}$ Cabinet also agreed that an "Amerindian Project Committee" be appointed to advise the government on the development of the community as the oldest sector of the country's multi-cultural society: "Amerindians have for some time, been recognised as having unique needs for the cultural and economic viability." The interesting aspect about this text is the term "representative of," which implies that only the indigenous community at Arima can be considered to be indigenous and not anyone else, should they claim to identify as such. Forte has termed this containment as "extinction by recognition" or "extinction by localization." 52 He proposes that the positing of Arima as home of the last remaining indigenous people is not supported by ethnographic research and asks why indigenous descendants would have mysteriously disappeared in Toco and Siparia (which were other missions that lasted as long as that of Santa Rosa) and not in Arima? This is a pertinent question, but the issue has been somewhat reconciled by the introduction of the category of indigenous in the most recent census, allowing for wider self-identification among the population (to be further discussed below).

A formal request of 400 acres of forested land in the Northern Range, with frontage in or near Arima, was made by the community in 1998 (although applications for land had been lodged for two decades prior to this date). The rationale for requesting land was framed in terms of both historical redress and contemporary socio-cultural development. The land would facilitate the community's wish "to survive and thrive," to "maintain indigenous life-ways," and to ensure a sociocultural model of sustainable development. ${ }^{53}$ 


\section{TOWARDS INDIGENOUS RIGHTS IN THE EASTERN CARIBBEAN}

The brief history of the islands' indigenous communities provided above displays the complexity of colonial encounters. In Trinidad, it was the establishment of the Spanish mission (itself a colonial endeavour) that ensured an amount of cohesiveness among the community in the one location at Arima. Likewise in Dominica, it was the establishment of the "Carib Reserve," borne out of a policy of containment, that ensured the cultural survival of the Kalinago. In Saint Vincent, the act of forced exile did not deter the Garifuna from maintaining their language and culture. On the contrary, the Garifuna still speak an Arawakan-derived language even though indigenous languages are no longer spoken on the islands themselves. ${ }^{54}$ Based on community activism, regional networking, and pressure from international human rights bodies, indigenous communities in the eastern Caribbean have gained significant strides in recent years in relation to recognition by their island governments. Although there is a lack of case law dealing with indigenous rights issues in the islands, the existence of jurisprudence and commentary of international human rights bodies helps to shed light on this progression, as well as on the outstanding issues on the ground.

\section{Dominica: From "Carib Reserve" to "Kalinago Territory"}

As mentioned above, the Carib Reserve Act was enacted just before independence in 1978 and granted common land title to the residents of the Kalinago Territory. Article 25(1) of the act provides that the Kalinago Chief and Council "have the sole custody, management and control of lands of the Reserve, for and on behalf of the residents of the Reserve." 55 At the same time, however, Article 48 of the act provides that the government shall retain responsibility for overall development and planning in the territory. While the act contributed significantly to the continuation of the Kalinago as a distinct cultural group in Dominica, it has also placed the community in a legal limbo and has been the subject of ongoing criticism since its inception. As one resident noted, the residents are much more aware of their rights now than when the act was passed in $1978 .^{56}$

The Carib "Reserve" was almost immediately renamed "Territory" by the Kalinago themselves. Criticisms of the act include the lack of clarification as to the territory's borders, as mentioned above, and the contradictory stance regarding land rights in and outside the territory between Kalinago and non-Kalinago. Article 51(2) of the Carib Reserve Act reserves the right of residence in the territory to those born in the territory or with Kalinago parentage as well as to anyone else who has lawfully resided in the territory for more than 12 years. This essentially means that a non-Kalinago can gain rights to reside inside the territory, yet, conversely, a Kalinago outside the territory does not have the same privilege. Unlike indigenous peoples elsewhere, Kalinago ancestry never implied inherited claims to collective rights or land outside the territory. 
Indigenousness in Dominica is thus inextricably tied to the Kalinago Territory itself. At various points in time, the government has proposed the privatization of lands in the territory as a solution to the problems of development and housing. Prior to independence in 1978 when the assimilationist policy was deemed the most suitable, petitions were sent to the administrator of Dominica by the then Chief Jermandois Francis and members of the Kalinago Council concerning the assimilationist policy planned for the reserve: "The Carib community have great pride in their history, their traditions and their communal integrity and are determined that these should not be forcibly submerged and erased by a deliberate assimilation." 57 Common land versus private property title is still a point of discussion at community meetings, but the belief that this would ultimately lead to the dissolution of the cultural fabric of the community has prevented it from becoming fact. As stated by former Chief Garnett Joseph, "land and our territory should be considered to have more than just monetary value. It's priceless because of the price paid by our ancestors." 58

Dominica voted in favour of adopting the UN Declaration on the Rights of Indigenous Peoples (UNDRIP) at the sixty-first session of the United Nations (UN) in 2007..$^{59}$ In addition, Dominica is the only member state of the Caribbean Community (CARICOM) to have ratified ILO Convention No. 169, which updated the earlier convention of the same name (Convention No. 107). ${ }^{60}$ While the latter convention was based on the assumption that indigenous peoples were temporary societies destined to disappear with "modernisation," Convention No. 169 recognizes that indigenous peoples are permanent societies and, thus, places importance on respect for ethnic and cultural diversity. The convention also emphasizes non-discrimination, self-determination, cultural rights, and development and contains numerous provisions on the lands and resources of indigenous peoples. ${ }^{61}$

In the most recent comments issued by the ILO Committee overseeing the monitoring of the convention, a number of requests for information were made to the Dominican government concerning Kalinago land rights. ${ }^{62}$ Specifically, the committee referred to the problematic aspects of the Carib Reserve Act (now Kalinago Territory Act) outlined above. The committee noted that, in relation to provisions under Article 17 of ILO Convention No. 169, section 45 of the Carib Reserve Act provides that no lands in the reserve can be sold, exchanged, mortgaged, encumbered, or disposed of without the written permission of the prime minister. Recalling that, under Article 17, paragraph 2, of ILO Convention No. 169, indigenous peoples shall be consulted whenever consideration is being given to their capacity to alienate their lands or otherwise transmit their rights outside the community, the committee asked the government to indicate how section 45 of the Carib Reserve Act is coordinated with section 47 of the act providing for the competence of the Kalinago Council of "custody and control" of the lands in the territory. ${ }^{63}$ The committee further requested the government to provide information on the socio-economic situation of the Kalinago people, the criteria used to 
estimate the size of the community, as well as information on the percentage of non-Kalinago residents in the territory.

In relation to the problem of encroachment in the territory, the ILO Committee requested the government to provide information on any cases of unauthorized intrusions upon the lands of the Kalinago Territory and the consequent measures taken. Considering that the government retains responsibility for overall development and planning in the territory (Article 48), the committee requested information on the government's "Integrated Development Plan" as well as the manner in which the Kalinago people were consulted about, and participated in, the elaboration of this plan and the extent to which it reflected their priorities for development. In relation to land rights and natural resources, the committee referred to the possibility in the act of granting additional lands (Article 44(1)) and whether the government has availed of this provision. The ILO Committee also requested the government to specify the legal regime applying to natural resources pertaining to the lands forming part of the Kalinago Territory, especially the "sub-soil resources," and the procedures in place to consult the people concerned in compliance with Article 15(2) of ILO Convention No. 169 in case the state retains the ownership of mineral or sub-surface resources or rights to other resources pertaining to those lands. Other comments dealt with the issues of discrimination against Kalinago children (Article 3 of ILO Convention No. 169) and health (Article 24-25 of ILO Convention No. 169).

From the "series failure to submit" reports, it is difficult to answer some of the questions posed by the ILO Committee, although some answers can be arrived at from a number of visits to the territory. In relation to Article 44(1) of the Carib Reserve Act, which provides for the possibility of allocating additional land, there has been no designation of new lands to the territory, and there is currently no known register of Kalinago and non-Kalinago in the territory. However, the government has taken a number of steps that meet its commitments under the ILO Convention No. 169 since the committee's comments were released (to be discussed in further detail below).

The Department of Carib Affairs (now the Department of Kalinago Affairs) was established in 2000 and represents Kalinago issues at government level. It became a ministry in 2005 with an increased remit-namely to formulate and implement community development projects; to facilitate community participation in decision-making processes concerning development; to work toward improving access to finance and credit for the Kalinago; to increase awareness of cultural heritage of the Kalinago; to collaborate with other departments and ministries; and to work toward socio-economic independence of the Kalinago people. ${ }^{64}$ The ministry has a staff of six individuals, including the minster for Kalinago affairs, a development officer, a project officer, a community liaison officer, and two administrative support staff, all of whom are of Kalinago descent.

Another recent development is the long overdue change of the name "Carib Reserve" (with all of its colonial associations) to "Kalinago Territory" (the preferred 
name of the community), which was made official and enacted into law in early 2015. ${ }^{65}$ According to the Ministry of Kalinago Affairs, which brought the Amendment Act to Parliament, the name change "represents the image of the Kalinago people in a more affirmative way, to reflect a better indigenous identity, to dispel the historic negative connotations lined with the word Carib." 66 In March 2015, for the first time in the territory's history, a cabinet of ministers met to discuss an agricultural support plan for local farmers, and one year previously an Indigenous Peoples Plan (funded by the World Bank) was published outlining a number of measures to support local agriculture and development, including road works, land stabilization, and agro-forestry targets. The plan was developed in consultation with community members. ${ }^{67}$ These initiatives are the result not only of international commitments concerning indigenous rights but also of persistent agitation on the part of diligent members of the Kalinago community themselves, thus continuing the tradition of activism of the Kalinago that was also reflected throughout the years in the many letters of petition addressed to the Foreign Office before Dominica's independence. ${ }^{68}$ The erasure of the term "Carib" from the nomenclature in Dominica is thus emblematic of more substantial progress in relation to indigenous rights in the island.

In sum, the outstanding issues for the residents of the Kalinago Territory are finally being addressed, but concerns remain in relation to socio-economic development and discrimination. There is also a lack of clarity over decision-making powers between the chief and the Council, on the one hand, and the Ministry of Kalinago Affairs and the government, on the other, and the split in responsibilities between them often results in tensions over decision making. While the Carib Reserve Act has been amended a number of times, including the change in terminology, a legislative overhaul might be required to consolidate amendments and clarify in law the exact nature of land rights for the Kalinago, including the rights to soil and subsoil, as well as to address the inconsistences of the current act in relation to decision-making powers and communication between the Kalinago Council and the Ministry of Kalinago Affairs. Perhaps the most important issue, however, is creating socio-economic sustainability for the community itself, the solution to which is complex and lies in agricultural incentives and creative credit solutions for the territory's residents and small-scale farmers.

\section{Saint Vincent: Re-appropriating "Yurumein"}

Saint Vincent and the Grenadines is not party to ILO Convention No. 169, but it did vote in favour of the UNDRIP and is party to a number other treaties, including the Convention on the Elimination of All Forms of Racial Discrimination $^{69}$ and the International Covenant on Economic, Social and Cultural Rights. ${ }^{70}$ As already noted, following the exile of the Garifuna at the end of the eighteenth century, the indigenous people who remained in Saint Vincent, more numerous than previously admitted, eventually ceased to speak their language and maintain 
their culture. The pejorative associations attached to being "Carib" meant that many adopted a conscious stance of non-identification-a sort of rejection of indigeneity. This has had ramifications right up to the present day. As commented on by the UN Special Rapporteur on Cultural Rights in 2012, "people identifying as Garifuna in Saint Vincent and the Grenadines today stated that during their youth, references to 'Black Caribs' were still very pejorative."

The most recent country report by the UN Committee on the Elimination of Racial Discrimination is also telling in this regard: "The Committee is concerned that no information has been provided by the State party on the economic, social and cultural situation of minority groups. It is further concerned that persons of Carib ancestry tend to be viewed as the base of the social pyramid and experience discrimination" and "the Committee recommends that the State party include in its next periodic report information on affirmative action measures in order to ensure the adequate development and protection of minority groups, in particular the Caribs." 72 The Special Rapporteur on Cultural Rights mentioned the lack of access to important historical documents as precluding cultural development and, interestingly, recommended consideration of the "importance of Balliceaux island for the Garifuna people and ensure that their relation to the island as a site of remembrance is respected and maintained." However, the rapporteur welcomed the Garifuna retrieval program launched by the government in 2002, with the support of the UN Educational, Scientific and Cultural Organization, as well as the work of the Garifuna Heritage Foundation, which is countering discrimination through awareness raising and the promotion of Garifuna cultural heritage.

Since these comments were written, a number of factors have improved on the ground in Saint Vincent. Chief Joseph Chatoyer, the last indigenous chief who was killed resisting the British at the end of the so-called "Black Carib War," has been made the first national hero of Saint Vincent and the Grenadines, and he is celebrated every year on National Heroes' Day. In March 2015, the second International Garifuna Conference was hosted in Saint Vincent, supported by the national government, with Garifuna delegations from Honduras, Belize, Guatemala, Nicaragua, and the United States in attendance. These delegations also made the annual pilgrimage to Balliceaux Island. References to "Carib" are now being replaced by the term "Garifuna."

Saint Vincent is perhaps the most active island state in re-appropriating the indigenous history and using it to construct a nation's story. Saint Vincent is leading the CARICOM commission on reparations for slavery and native genocide against the governments of Britain, France, and the Netherlands. ${ }^{73}$ With assistance from the London-based law firm Leigh Deigh, the claim includes an indigenous component, with "native genocide" included in the title and an "indigenous peoples development programme" included within the 10-point plan for reparations. Interestingly, the historical appropriation of indigenous lands is mentioned in this part of plan, even though the question of land restitution falls 
within the jurisdiction of present day island states. However, the prime minister, Ralph Gonsalves, recently pledged during his National Heroes Day speech that the government would begin titling indigenous lands in Saint Vincent. ${ }^{74}$

The preservation of Balliceaux Island as a sacred site and enabling access by the Garifuna is also an important issue. As previously mentioned, Balliceaux was the subject of a plea on the part of the Garifuna Council of Belize to the government of Saint Vincent in 2005 in an attempt to block its private sale for tourist development. The private island is still for sale for the price of US \$30 million, a fact that has caused much consternation among Vincentians and the Garifuna diaspora and that has ignited a debate over possible conservation mechanisms. Indeed, according to National Trust Amendment Act No. 37, the National Trust is authorized to declare any site as "protected national heritage," which it has already done for the neighbouring island of Battowia, a designated wildlife reserve and one of the five breeding sites of frigate birds in the Caribbean. ${ }^{75}$ Another option would be the compulsory purchase of the island by the government with a view to its preservation and the creation of a memorial or visitor centre. According to the Land Acquisition Act of 1946, the government may issue a compulsory purchase order, provided that adequate compensation is provided to the owners of said land. ${ }^{76}$ Yet the cost of compensation to be paid under such an order would likely be prohibitive, and this also raises the question whether the state of Saint Vincent should bear the burden of preserving a site that is directly linked to genocidal acts committed by the British government.

\section{Trinidad: "Writing the Indigenous People Back In"}

In 1962, when Trinidad and Tobago gained independence from Great Britain, the prime minster, Eric Williams, published "the first full and authoritative history" of the country. ${ }^{77}$ The first chapter of 16, entitled "Our Amerindian Ancestors," is the only section of the book dedicated to the indigenous population and is written entirely in the past tense. Even though Williams was a unifier and an authority on Caribbean history, the scant attention he paid to indigenous presence in this volume was based on the premise that the indigenous people were part of the past, not the present, multi-ethnic societal make-up of the country. As noted by Bridget Brereton, "for too long, the 'extinction narrative' prevailed in T\&T and the Caribbean islands (not in Guyana or Belize). This insists that all the Amerindians were 'wiped out,' they 'disappeared,' and they are no longer part of the living history of these islands." 78 Thus, the indigenous people of Trinidad had the additional challenge of proving their survival.

Although not a state party to ILO Convention No. 169, Trinidad and Tobago also voted in favour of adopting the UNDRIP. This declaration specifically mentions the right of indigenous people to "practice and revitalize their cultural traditions and customs. This includes the right to maintain, protect and develop the 
past, present and future manifestations of their cultures."79 The declaration also provides for the "right to the lands, territories and resources which they have traditionally owned, occupied or otherwise used or acquired" and the "right to redress, by means that can include restitution or, when this is not possible, just, fair and equitable compensation, for the lands, territories and resources which they have traditionally owned or otherwise occupied or used, and which have been confiscated, taken, occupied, used or damaged without their free, prior and informed consent." 80

Trinidad is party to a number of relevant human rights treaties, which unlike the UNDRIP are binding in character and which include provisions relating to the rights of indigenous peoples and minorities, including cultural rights, namely the International Covenant on Civil and Political Rights (ICCPR) ${ }^{81}$ and the International Covenant on Economic, Social and Cultural Rights, which both expand on the normative content of the Universal Declaration on Human Rights. ${ }^{82}$ Article 27 of the ICCPR provides:

In those states in which ethnic, religious or linguistic minorities exist, persons belonging to such minorities shall not be denied the rights, in community with the other members of their group, to enjoy their own culture, to profess and practice their own religion, or to use their own language.

Although worded in negative terms ("shall not be denied the right"), General Comment No. 23 of the UN Human Rights Committee makes clear that the obligations pertaining to cultural rights in Article 27 are not only negative but also positive in nature. ${ }^{83}$ This means that the state has to take an active role in the facilitation of the cultural development of its minorities, including indigenous peoples. Trinidad is also party to the UN Convention on the Elimination of all Forms of Racial Discrimination. ${ }^{84}$ Between 1980 and 2006, the concluding observations of the UN Committee on the Elimination of Racial Discrimination (CERD) made continuous reference to the lack of a specific category for the recognition of indigenous people as a separate ethnic group, urging the government to actively seek consultations with the indigenous population as to how they prefer to be identified, as well as on policies and programs affecting them. ${ }^{85}$ In addition to the right to self-identify, however, the CERD also referred to "positive measures to protect and encourage the economic and social progress of the Carib people" 86 as well to the "preservation of cultural identity" 87 and, importantly, "compensation for historical injustice they suffered." 88 According to the CERD, therefore, the state has a current responsibility toward the indigenous community in providing some form of redress.

Indeed, in 2011, the national population census was amended to include the category of "indigenous," thus inserting the indigenous population back into the official record for the first time in over 150 years. Prior to this recognition, the "mixed" heritage category was intended to fulfil this role. As stated by the national census report for the year 2000, the population "consists of groups of persons 
with backgrounds from Europe, Africa, and Asia (mainly, Chinese, Indians, and Syrian-Lebanese); along with a small group of Caribs who are the descendants of the indigenous Amerindians. ... it is believed that small remnants among them are included with mixed groups." 89 In the 2011 census, the number of people who identified as being "indigenous" was 1,461, while some 201,328 persons identified as "mixed-other" (separate from an additional mixed category of "mixed-African and East Indian heritage"). ${ }^{90}$ It is conceivable therefore that persons who previously ticked the "mixed" box, might have continued to do so since "there are still thousands of people in T\&T today who are descended from those peoples, even if they don't (yet) know it."91 The next census will be revealing in this regard. There is also a newer organization, the Elders Council of the Warao Community, which is based in the south and represents the Warao people.

The insertion of the category of indigenous into the population census was due not only to the consistent negative commentary by the CERD outlined above but also to the steady agitation on the part of the Santa Rosa First Peoples' Community itself. In addition, Amerindian Heritage Day has been transformed into Indigenous Heritage Week, with government support. More recently, in October 2015, the government finally granted access to the 25 acres of land that had been officially promised to the community since December 2012. Although it is a small fraction of what the community originally held in collective tenure, this 25 acres, which is government-owned land situated in the forest area of the northern range, is intended as a site on which to build a model "Amerindian village," which will function as a centre point for community activities.

\section{CONCLUSION}

To conclude, indigenous communities in all three islands have cleverly articulated their calls for indigenous rights through the use of cultural heritage and the language of international human rights standards. This action illustrates what Ronald Niezen terms "international norm diffusion," essentially how global concepts of rights are shaped in practice by communities who see themselves as subjects of those rights. ${ }^{92}$ This has resulted in a number of developments in recent years concerning recognition and restitution in the islands. First, there has been state recognition in the form of support for the cultural activities of the communities in all three islands: for the Santa Rosa Festival and Indigenous Heritage Week in Trinidad; for the Garifuna Heritage Foundation and the International Garifuna Summit in Saint Vincent; and for the Ministry of Kalinago Affairs and cultural groups in Dominica.

Second, the term "Carib" has been erased from official nomenclature and documentation in all three islands. The Santa Rosa "Carib" Community is now called the "First Peoples" Community; the "Carib Reserve" is now officially renamed the "Kalinago Territory" (with the corresponding name change in the Kalinago Territory Act); and in Saint Vincent, the word Garifuna has all but replaced the 
term "Carib." This gradual erasure of the term "Carib" in all three cases symbolizes the re-appropriation of indigenous space in the islands. Another significant development is the introduction in the most recent population census of the possibility to self-identify as indigenous, the first time citizens of Trinidad and Tobago have been able to do so since independence and the first time indigenous people have been registered in official records since the mid-nineteenth century. The government of Trinidad has also recently granted access to the 25 acres it promised to the Santa Rosa First Peoples Community some years ago. Although this is a fraction of what the community is owed, it is still an achievement and represents a stepping stone for the community with a view to gaining further land in the future. In Saint Vincent, the government has recently pledged to title indigenous lands, and in Dominica, the government is in the process of mapping the Kalinago Territory and introducing agro-forestry support programs for the Kalinago Territory, with external support.

Despite these developments, however, issues do remain in relation to discrimination and socio-economic development in the islands. In order for these to be overcome, the governments of Dominica, Saint Vincent, and Trinidad must follow through on their recent promises concerning land security, land titling, and access to land respectively. In Dominica, this goal requires clarifying the exact nature of land rights for the Kalinago, including rights to soil and subsoil, as well as creating agricultural incentives and credit solutions for the residents of the territory. In addition, there needs to be some clarification of the decision-making powers between the Kalinago Council and the Ministry of Kalinago Affairs. In Saint Vincent, it means properly addressing the lack of title for those communities in traditionally occupied areas as well as preserving access to Balliceaux Island as a cultural landscape and pilgrimage site. Such action is necessary if communities are to meaningfully regain some of the loss they suffered historically and to complete the circle of revival to restitution in both a symbolic and literal sense.

\section{ENDNOTES}

1. One of the related sub-projects within this European Research Council project is examining the trajectory of Caribbean collections to European museums. It is being conducted by M. Françozo. For more information, see http://www.nexus1492.eu.

2. This is the general dual meaning offered up by standard English language dictionaries. See, e.g., Oxford English Dictionary, http://www.oxforddictionaries.com/definition/english/restitution (accessed 15 January 2016).

3. Belle Antoine 1998, 4.

4. Ibid., 5 .

5. This article builds on the scholarship scrutinizing the notion of indigenous absence in the Caribbean. See, in particular, Newton 2013, 2014; Forte 2006, 2013.

6. See, e.g., Moiwana Village v. Suriname, IACtHR, Series C, No. 124, paras. 86.5 and 130 (15 June 2005); Case of the Saramaka People v. Suriname, IACtHR, Series C, No. 172, para. 214 (28 November 2007); Kalina and Lokono Peoples v. Suriname, Case 198-07, Report No. 76/07, 
IACtHR, OEA/Ser.L/V/II.130, Doc. 22, rev. 1 (2007); Maya Leaders Alliance v. Attorney General of Belize, [2015] CCJ 15 (30 October 2015).

7. Ginés de Sepúlveda 1979; de Las Casas 1999.

8. Locke 1988; Hobbes, cited in Boucher 1992.

9. Preliminary articles between Great Britain, France and the States General, signed at Aix-laChapelle (19 April 1748, OS/30 NS). SP 108/104. British National Archives, Kew.

10. See, for example, Strauman and Benton 2010; Pemberton 2013.

11. Bulkan 2011.

12. Forte 2006.

13. Haslip Viera 2001, 2013.

14. Niezen 2010, 3.

15. Hulme 2001, 295.

16. Reid 2009, 88.

17. Lestringant 1997; Reid 2009, 88-100.

18. Chaguaramas Development Authority, http://www.chagdev.com/History/AmerindianOccupation [No longer available].

19. Honychurch 1997. The term "Kalinago" is used here except when referring to documents and legislation that used, or continue to use, the term "Carib." The same goes for the use of the term Garifuna. "Carib" is a contested term and holds negative associations for indigenous communities in the islands. However, up until recently, communities were using the term themselves, and UN Human Rights bodies use the term in recent reports. For a discussion of early European relations with the Kalinago, see Boucher 1992.

20. On the 1660 Treaty, see Boucher 1992, 51-52; and on the 1668 Treaty, see Colonial Office, St. Vincent Original Correspondence, Petition to Their Excellencies the Lord Justices, Doc. CO 260/3 (2 October 1719), Records of the Foreign Office, British National Archives (hereafter BNA).

21. Administrator Bell to Mr. Chamberlain, Report on the Caribs of Dominica, CO 152/425/1, 77, para. 38 (29 July 1902), BNA.

22. Carib Reserve Act 1978, c. 25:90, http://www.dominica.gov.dm/laws/chapters/chap25-90.pdf (accessed 15 January 2016).

23. International Labour Organization (ILO), Convention No. 169 Concerning Indigenous and Tribal Peoples in Independent Countries (hereafter ILO Convention No. 169), 28 ILM 1382 (1989), Art. 1(1)(b).

24. de Albuquerque and McElroy 1999; Pan-American Health Organization (PAHO) 1999.

25. Caribbean Development Bank 1999, 18.

26. It also noted, however, that this had improved from a figure of $70 \%$ in 2003.

27. Patterson and Rodriguez 2003.

28. Workshop on Land Issues, 111th Anniversary of the Establishment of the Carib Territory, Kalinago Barana Autê, Crayfish River, Dominica, Minutes of Meeting (4 July 2014).

29. Report on the Caribs of Dominica, para. 36.

30. Taylor 2012, 9. For a critical analysis of the shipwreck story, see Newton 2014, 18.

31. Taylor 2012, v.

32. Ibid., 160-64.

33. The indigenous languages of the Caribbean (including Ciboney Taíno, Macorís, Ciguayo, Guanahátabey, Kalíphuna, Karina Carib) are no longer spoken on the islands. See Granberry 2013.

34. Foster 1987.

35. Thorne 2004, 23.

36. Letter of 30 June 2005 to the Honorable Ralph Gonsalves, Prime Minister of Saint Vincent and the Grenadines, from the National Garifuna Council of Belize, on the pending sale of Balliceaux Island, http://www.ngc.org (accessed 15 January 2016).

37. People from Greiggs still maintain their community was founded by holdouts from the "Second Carib War" who had remained hidden for years in the shadow of Petit Bonhomme Mountain. See Taylor 2012, 180.

38. Newton 2014, 19. 
39. In 1802, 5,262 acres of "Carib" lands were distributed to different persons who had been engaged in the "war." An act was passed in 1804 declaring that by the rebellion, the "Caribs" had forfeited all claim to their lands under the treaty of 1773, and these were revested in the Crown. The remaining Kalinago were "pardoned' in 1805 on condition that they surrender and submit to laws, the act of which expressly negated their right to any of the lands formerly occupied by them. They were granted approximately 230 acres near Morne Ronde for their subsistence. Shephard 2013, 139-40.

40. See, e.g., the case of Sarstoon-Temash National Park: Sarstoon-Temash Institute for Indigenous Management (SATIIM) et al. v. Attorney General of Belize, Claim No. 394 of 2013, Judgment 3 April 2014, Claim No. 394 of 2013, Judgment of 3 April 2014, http://www.belizejudiciary.org.

41. Palacio, Tuttle, and Lumb 2011.

42. Boomert 2016.

43. Forte 2003.

44. Forte and Bharath Hernandez 2006.

45. The community was formally known as the "Santa Rosa Carib Community." According to the chief, this name change was due to the emerging historical evidence pointing to the existence not only of Kalinago ("Caribs") but also other tribes, such as Nepuyo, at Arima. The new name of the community is intended to be more inclusive and historically accurate, but it also reflects a move away from the term "Carib," which has derogatory associations for indigenous communities in the region. Personal communication with Ricardo Bharath Hernandez, Arima, 17 May 2014.

46. Various dates for the establishment range between 1784 and 1786, but most agree on 1786. The date used here is that used by the Arimian, Jean Paticia Elie (1990), in her historical account of the Parish of Santa Rosa de Arima.

47. Forte 2003. The Cédula of Population was an edict enacted in 1783 opening Trinidad up to immigration from predominantly French Caribbean Islands. It invited persons of Roman Catholic faith who would swear loyalty to the Spanish Crown in return for land allotments, and contributed considerably to the population growth of Trinidad.

48. See, e.g., De Verteuil 1858, 172.

49. Elie 1990, 4.

50. Santa Rosa First Peoples' Community, http://www.santarosafirstpeoples.org/carib-queens/ (accessed 15 January 2016). This section was researched by M.C. Forte.

51. Information Division, Office of the Prime Minister of Trinidad and Tobago, Press Release No. 360 .

52. Forte 2013, 187-88.

53. Granberry 2013.

54. An Amerindian Heritage Complex, a Project Proposal by the Santa Rosa Carib Community (1998), http://www.santarosafirstpeoples.org/ (accessed 15 January 2016).

55. Carib Reserve Act 1978, c. 25:90.

56. Personal communication with former Kalinago Chief, Irvince Auguiste, Kalinago Territory, July 2014.

57. Assimilation of the Carib Community into the Rest of Dominica: Representations, CO 1031/5274, January 1966-December 1967, Records of the Colonial Office, BNA.

58. Joseph 2014.

59. United Nations Declaration on the Rights of Indigenous Peoples (UNDRIP), GA Res 61/295, UN GAOR, UN Doc A/RES/61/295, 13 September 2007.

60. ILO Convention No. 169; International Labour Organization, Indigenous and Tribal Populations Convention, C107, 26 June 1957, http://www.refworld.org/docid/3ddb66804.html (accessed 15 January 2016).

61. Art. 15 provides the right to the use management and conservation of their resources. Art. 2 provides for the participation of peoples. Art. 4 provides for safeguarding measures for the environment of such peoples with their freely expressed wishes. Art. 6 provides that the state must consult, and Art. 7 also provides for participation in environmental impact assessment. A right to remedy is provided in Art. 12. 
62. See Direct Request (CEACR) 2014, 104th International Law Commission Session 2015, http:// www.ilo.org/dyn/normlex/en/.

63. Ibid., Art. 17.

64. Ministry of Kalinago Affairs, http://kalinagoaffairs.gov.dm/ http://www.ilo.org/dyn/normlex/en/ (accessed 15 January 2016).

65. At the first meeting of the first session of the Ninth Parliament, the Carib Territory Amendment Act was passed in February 2015, replacing the term in all official documents.

66. Workshop on Land Issues, 111th Anniversary of the Establishment of the Carib Territory, Kalinago Barana Autê, Crayfish River, Dominica, Minutes of Meeting (4 July 2014).

67. Indigenous Peoples Plan, http://kalinagoaffairs.gov.dm/index.php/latestnews/24-indigenouspeoples-plan (accessed 15 January 2016).

68. See, e.g., Conditions on Carib Reserve, Dominica, CO 152/431/6; Situation in Carib Reserve, Dominica including Petition to the King, CO 152/462/6; Petition from Carib Subjects for the Granting of a Reserve and the Appointment of Thomas John as Chief, CO 152/406/7, all in Records of the Colonial Office, BNA.

69. International Convention on the Elimination of All Forms of Racial Discrimination, 21 December 1965, 660 UNTS 195 (hereafter Convention on Racial Discrimination 1965).

70. International Covenant on Economic, Social and Cultural Rights, 16 December 1966, 993 UNTS 3.

71. Shaheed 2013, para. 64(g).

72. UN Committee on the Elimination of Racial Discrimination (CERD) 2003, para. 10.

73. A separate article by this author deals with the Caribbean reparations case; see Strecker 2016. As well, please see "CARICOM nations unanimously approve 10 point plan for reparations," Leigh Day, 11 March 2014, http://www.leighday.co.uk/News/2014/March-2014/CARICOM-nationsunanimously-approve-10-point-plan (accessed 15 January 2016).

74. Although it must be noted the lack of title is not unique to indigenous communities. See P. Isaacs, "Issue Paper on Sustainable Land Management, St. Vincent and the Grenadines," July 2013, http://www.housing.gov.vc/housing/images/stories/issue\%20paper\%20svg.pdf (accessed 15 January 2016). Land reform is an issue affecting many communities in Saint Vincent and, indeed, the region. A separate article by this author will be devoted to the question of land reform in the Caribbean more generally.

75. National Trust Amendment Act No. 37 (2007).

76. Land Acquisition Act 1946 (revised).

77. Williams 1962.

78. Brereton 2014.

79. UNDRIP, Art. 11.

80. Ibid., Arts. 26 and 28.

81. International Covenant on Civil and Political Rights, 16 December 1966, 999 UNTS 171.

82. Universal Declaration of Human Rights, 1948, UN Doc. A/810, 1948.

83. Human Rights Committee, General Comment 23, reprinted in Compilation of General Comments and General Recommendations Adopted by Human Rights Treaty Bodies, UN Doc. HRI/GEN/1/ Rev.1, 1994, 38, Art. 27.

84. Convention on Racial Discrimination 1965.

85. CERD, Concluding Observations 1980-2006, http://www.ohchr.org/EN/HRBodies/CERD (accessed 15 January 2016).

86. Report of the Committee on the Elimination of Racial Discrimination, Official Records: 39th Session, New York, 1984. Supplement No. 18 (A/39/18), para. 198, http://www.ohchr.org/en/ hrbodies/cerd/pages/cerdindex.aspx.

87. Report of the Committee on the Elimination of Racial Discrimination, Official Records: 36th Session, New York, 1981. Supplement No. 18 (A/396/18), para. 436, http://www.ohchr.org/en/ hrbodies/cerd/pages/cerdindex.aspx. Although, it must be pointed out that cultural identity is constantly in flux and therefore cannot really be "preserved" but, rather, supported. The language of the committee has progressively developed since then. 
88. Report of the Committee on the Elimination of Racial Discrimination, Official Records: 50th Session, New York, 1998. Supplement No. 18 (A/50/18), para. 34.

89. CARICOM Capacity Development Programme 2000.

90. Central Statistics Office 2011.

91. Brereton 2014.

92. Niezen 2010, v. 3.

\section{REFERENCES}

Belle Antoine, Rose-Marie. 1998. Law and Legal Systems in the Commonwealth Caribbean. New York: Cavendish.

Boucher, Philip. 1992. Cannibal Encounters, Europeans and Island Caribs, 1492-1763. Baltimore: John Hopkins Press.

Boomert, Arie. 2000. Trinidad, Tobago and the Lower Orinoco Interaction Sphere, An Archaeological/ Ethnohistorical Study. Leiden: Leiden University.

- 2016. The Indigenous Peoples of Trinidad and Tobago from the First Settlers until Today. Leiden: Sidestone Press.

Bulkan, Arif. 2011. "From Instrument of Empire to Vehicle for Change: The Potential of Emerging International Standards for Indigenous Peoples of the Commonwealth Caribbean." Commonwealth Law Bulletin 37, no. 3: 463-89.

Brereton, Bridget. 2014. “The First Peoples Narrative in Trinidad and Tobago." Review of the Indigenous Caribbean, http://www.indigenousblogspot.nl/2014/11 (accessed 15 January 2016).

Caribbean Development Bank. 1999. Country Poverty Assessment-Dominica, Final Report, http:// www.caribank.org/uploads/publications-reports/economics-statistics/country-poverty-assessmentreports/Dominica (accessed 15 January 2016).

CARICOM Capacity Development Programme. 2000. National Population Census Report 2000, Trinidad and Tobago, http://www.caricomstats.org/Files/Publications/NCR\%20Reports/ (accessed 15 January 2016).

Central Statistics Office, Government of Trinidad and Tobago. 2011.2011 Population and Housing Census, http://www.cso.gov.tt (accessed 15 January 2016).

CERD. 2003. "UN Committee on the Elimination of Racial Discrimination: Concluding Observations, Saint Vincent and the Grenadines." Doc. CERD/C/63/CO/10, http://www.refworld.org/ docid/403e144a2.html (accessed 15 January 2016).

De Albuquerque, K., and J. McElroy. 1999. "Race, Ethnicity, and Social Stratification in Three Majority Afro-Caribbean Societies." J.E. Caribbean Studies 24, no. 4: 1-29.

De Verteuil, L. A. A. 1858. Trinidad, Its Geography, Natural Resources, Administration, Present Condition, and Prospects. London: Ward and Lock.

Elie, Jean Paticia. 1990. A Short History of Santa Rosa de Arima 1749-1900. St. Augustine, Trinidad and Tobago: University of West Indies Press.

Forte, Maximilian. 2003. "How the Amerindians of Arima Lost Their Lands, Notes from Primary and Other Historical Sources, 1802-1880: A Report Prepared at the request of the Santa Rosa Carib 
Community of Arima, Trinidad," https://indigenouscaribbean.files.wordpress.com/2008/05/landreport. pdf (accessed 15 January 2016).

_. 2006. Indigenous Resurgence in the Contemporary Caribbean. New York: Peter Lang.

2013. Who Is an Indian? Race, Place, and the Politics of Identity in the Americas Toronto: University of Toronto Press.

Forte, Maximilian, and Ricardo Bharath Hernandez. 2006. "In This Place Where I Was Chief: History and Ritual in the Maintenance and Retrieval of Traditions in the Carib Community of Arima, Trinidad." In Indigenous Resurgence in the Contemporary Caribbean, edited by Maximilian Forte, 107-32. New York: Peter Lang.

Foster, Bryon. 1987. “Celebrating Autonomy: The Development of Garifuna Ritual on St. Vincent.” Caribbean Quarterly 33: 75-83.

Ginés de Sepúlveda, Juan. 1979. Tratado sobre las justas causas de la guerra contra los indios, Meléndez y Pelayo, Marcelino, edited by Manuel García-Pelayo. Mexico City: Fondo de Cultura Económica.

Granberry, Julian. 2013. "Indigenous Languages of the Caribbean.” In Oxford Handbook of Caribbean Archaeology, edited by Corinne Hofman, William Keegan, and Renial Rodríguez Ramos, 61-69. Oxford: Oxford University Press.

Haslip Viera, Gabriel. 2001. Taíno Revival: Critical Perspectives on Puerto Rican Identity and Cultural Politics. Princeton: Markus Weiner.

2013. Race, Identity, Politics, Puerto Rican Neo-Tainos in the Diaspora and the Island. New York: Latino Studies Press.

Honychurch, Lennox. 1997. Carib to Creole: Contact and Culture Exchange in Dominica. PhD dissertation, Oxford University.

Hulme, Peter. 2001. "Survival and Invention: Indigeneity in the Caribbean.” In Postcolonial Discourses: An Anthology, edited by G. Castle, 293-308. Oxford: Blackwell Publishing.

de Las Casas, Bartolomé. 1999. A Short Account of the Destruction of the Indies, translated by Nigel Griffin, introduction by Anthony Pagden. London: Penguin Books.

Lestringant, F. 1997. Cannibals: The Discovery and Representation of the Cannibal from Columbus to Jules Verne. Berkeley: University of California Press.

Locke, John. 1988 [1689]. Two Treatises of Government, edited by Peter Laslett. Cambridge: Cambridge University Press.

Newton, Melanie J. 2013. "Returns to a Native Land: Indigeneity and Decolonization in the Anglophone Caribbean.” Small Axe 17, no. 2: 108-22.

- 2014. "'The Race Leapt at Sauteurs': Genocide, Narrative and Indigenous Exile from the Caribbean." Special issue on the Garifuna people, edited by Joseph Palacio. Caribbean Quarterly 60, no. 2: 5-28.

Niezen, Donald. 2010. Public Justice and the Anthropology of Law. Cambridge: Cambridge University Press.

PAHO. 1999. Basic Country Health Profiles. PAHO: Ecuador. 
Palacio, Joseph O., Carlson J. Tuttle, and Judith R. Lumb. 2011. Garifuna Continuity in Land: Barranco Settlement and Land Use 1862-2000. Belize: Producciones de la Hamaca.

Patterson, T., and L. Rodriguez. 2003. "Political Ecology of Tourism in the Commonwealth of Dominica." In Tourism and Development in Tropical Islands: Political Ecology Perspectives, edited by S. Gössling, 60-87. Cheltenham, UK: Edward Elgar.

Pemberton, Jo-Anne C. 2013. "The So-Called Right of Civilization in European Colonial Ideology from the 16th to 20th Centuries." Journal of the History of International Law 15: 25-52.

Reid, Basil. 2009. Myths and Realities of Caribbean History. Tuscaloosa: University of Alabama Press.

Shaheed, Farida. 2013. "Report of the Special Rapporteur in the Field of Cultural Rights, on Her Mission to St. Vincent and the Grenadines (5-9 November 2012)." Doc. A/HRC/23/34/Add.2, http:// www.refworld.org/docid/ (accessed 15 January 2016).

Strauman, B., and L. Benton. 2010. "Acquiring Empire by Law: Roman Doctrine to Early Modern European Practice." Law and History Review 28, no. 1: 1-38.

Taylor, Christopher. 2012. The Black Carib Wars, Freedom, Survival and the Marking of the Garifuna. Oxford: Signal Books.

Thorne, E. 2004. Land Rights and Garifuna Identity. North American Congress on Latin America (NACLA) Report on the Americas 38, no. 2. New York: NACLA.

Vitoria, Francisco de. 1991. "On the American Indians." In Political Writings, edited by Anthony Pagden and Jeremy Lawrence, 231-92. Cambridge: Cambridge University Press.

Williams, Eric. 1962. History of the Peoples of Trinidad and Tobago. Port of Spain: PNM Publishing. 